\title{
BOJHO БЕСЕДНИШТВО
}

\author{
Карина Авагјан \\ Универзитет у Београду, Филолошки факултет
} анализирају као књижевна дела из различитих перспектива: композицијски, стилски, према циљу и предмету говора. Беседе су биране по принципу хронолошких збивања кроз историју ратовања, од античких времена до Другог светског рата. Биране су тако да се пореде два говора представника супротстављених снага уочи битке, при чему је извесно како су се битке одиграле и у чију су се корист окончале.

Кључне речи: војно беседништво, беседе, говорник, реторика, анализа, композиција, стилске фригуре, ауторитет

\section{Појам и термини}

$B_{p}^{o}$ ојно беседништво као правац реторике старо је колико и она сама, јер су се ратови водили од почетка људске цивилизације. У антици је било незамисливо да војсковођа или владар буде рђав говорник. У вези с тим Филип II је рекао: „Да сам слушао речи Демостена ${ }^{1}$ (упућене против њега - Филипа) обавезно би гласао за рат против себе". Снага беседништва је била моћно оруђе за сваког ко је желео да поведе народ за собом. У одлучујућим тренуцима јака реч и исправан став ауторитативног вође умели су да покрену посусталу војску. Због тога се од античких времена до данас реторика проучава у свим војним институцијама - у војним школама и на војним академијама реторика је обавезан предмет. Кадети се такмиче у реторичким вештинама, сами пишу своје беседе, а такмиче се и у интерпретацији познатих оратора. На крају школовања у обавези су да одрже свечану беседу поводом завршетка студија, а најбољи говорници улазе у анале те образовне институције.

Око назива тог жанра реторике постоји одређена полемика. Бранислав Нушић, који је издао и први уџбеник реторике на српском језику, назван Војничко беседништво, класифрикује војничке беседе на: свечане, пригодне и ратничке. Под свечаним (војничким) беседама Нушић је подразумевао беседе које старешине говоре о појединим већим држав-

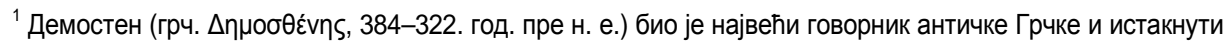
атински државник. Његови говори одликују се високом књижевно-уметничком вредношћу и истовремено пружају темељит увид у политичка и културна збивања у античкој Грчкој током 4. века старе ере. Демостен је будно пратио Филипове успехе и опомињао Атињане на опасност која прети од македонског краља не само Атини већ и читавој Грчкој. Он је сматрао да се та опасност може отклонити само правовременим и одлучним ратом. То своје уверење изразио је у свом првом говору против Филипа, одржаном 351. године, у којме оштро напада неактивност и млитавост Хелена и предлаже да се опреми војска у којој би били и атински грађани, а не само разни најамници, те да се та војска бродовима отпреми у северно море да замара и слаби Филипа препадима и пљачкањима.
} 
ним или војничким свечаностима или приликом посебног свечаног чина, нпр. о Краљевом дану, о државним празницима, приликом предаје одликовања застави, полагања заклетве и сл. Такве беседе састављају се унапред, поштујући сва правила беседничке вештине, при чему се строго води рачуна о приступачности и разумљивости текста, тако да буде јасан свим слушаоцима. Предмет беседе код њих је непроменљив, може се понављати и ретко кад је спонтан. Беседник при говору свечане војничке беседе мора заузети сталожен став, имати одмерене покрете, а његов глас мора да одаје достојанство и свечаност. Пригодним беседама Нушић назива оне беседе које се говоре у различитим приликама војничког живота. Ту спадају и надгробне беседе, као и беседе које се говоре приликом заклетве регрута, поздрава новом команданту, или његова реч приликом примања јединице, предаје одликовања појединцима итд. Предмет говора у таквим беседама највећим делом је случајан, па се пригодна беседа често импровизује на лицу места. Став говорника током пригодне беседе је мало слободнији него код свечаних беседа, као и гестикулација. Ратничке беседе Нушић сматра најважнијом врстом војничког беседништва. Оне имају за циљ да подигну морал војника, изазову ратничко расположење, да их подстакну на пожртвовање и да им предоче значај ратничке славе. Беседник говори са великим патосом и високим тоном. Овакве беседе не морају поштовати правила говорничких вештина, већ одишу снажном емоцијом, која се изражава у што мањем броју реченица. Ту важи само једно правило, а то је да ратничка беседа мора бити кратка, јасна и снажна. Ратничке беседе се говоре уочи битке или после ње. У првом случају њихова сврха је у да се охрабре војници, а у другом да се похвале њихова храброст и пожртвованост.

Сима Аврамовић у књизи Rhetorika techne посветио је посебан одељак војном беседништву, при чему га, као и Нушић, назива војничким говором. Други аутори који су се бавили сакупљањем беседа те врсте, пре свега Чедомир Вајдић ${ }^{2}$ и Радослав Љубибратић, ${ }^{3}$ своје збирке називају Војне беседе. Будући да су обојица били официри, аутор тог рада преферира њихов израз, сматрајући га адекватнијим. Наиме, придев војнички настао је од војник, док је придев војно настао од корена вој, што је код древних Словена значило рат. Словени су, као и Келти, пред сваку битку испуштали крике и правили што већу буку да би заплашили своје противнике ${ }^{4}$ Корен вој у савременом српском језику задржао се у дериватима: војник, војно, војенштина, војвода итд., а у руском и у именици война/рат. Дакле, војно у српском језику има шире значење и од војничко и од ратничко, а самим тим чини нам се прикладнијим за назив беседа те врсте јер се не односи само на војнике, нити такву беседу држе војници, већ је, напротив, обично говоре високи официри.

\section{Одабране војне беседе и њихова анализа}

Настојаћемо да прикажемо анализу војне беседе као анализу књижевног дела. Беседе су биране тако да се пореде два говора представника супротстављених снага. Размотрићемо беседе из различитих перспектива: композицијски, стилски,

\footnotetext{
${ }^{2}$ Вајдић Ч., Беседе, избор из војничког беседништва, Београд, 1996.

${ }^{3}$ љубибратић Р., Војне беседе, Београд, 1987

${ }^{4}$ Вој - вапај, крик, арлаукање; Фасмер Макс, Этимологический словарь русского языка, Москва, 1960.
} 
према циљу и предмету говора. Интересантно је упоредити две беседе уочи битке, при чему је извесно како су се битке одиграле и у чију су се корист окончале. Беседе су биране по принципу хронолошких збивања кроз историју ратова од античких времена до Другог светског рата. Због ограничења постављених обимом рада и доступности забележеног материјала (опозиционих говорника), аутор ће се ограничити на беседе познатих и значајних војсковођа.

1. Ханибал Барка (247-183. пре н. е.)

Беседа пред битку на Тразименским језерима, коју је Ханибал Барка изгубио од Публија Корнелија Сципиона.

Другови!

Небо ми обећава победу. Не нама, но Римљанима се ваља бојати. Погледајте на бојно поље, тамо нема места за кукавице. Сви до једног ћемо изгинути ако не победимо! Шта нам може поузданије обезбедити победу до такав завет; шта ли од таквог завета може чвршће усадити у нама веру да нас небо заштићује?!?

Другови! Богови нас поставише између победе и смрти!

Увод, а уједно и титулисање у овој беседи своди се на једну лексему - Друго$8 u^{5}$, али је она набијена емоцијама (фактор pathos) и војницима треба да створи слику присности и искреног односа с војсковођом.

Мотив беседе је побуђивање ратничког духа код војника, истицање војничке части, славољубља и вере у победу. Да би говор изгледао убедљивије беседник га поткрепљује аргументима, који се у војним беседама најчешће одражавају у Божјој наклоности, односно вољи богова.

У закључном делу говорник се опет обраћа војсци као на почетку говора са Другови, чиме истиче пријатељски однос с подређенима, а реченицом „Богови нас поставише између победе и смрти!" даје могућност избора војницима, тј. наводи их да помисле да само од њих зависи исход те битке, коју не смеју да изгубе уколико желе да остану у животу.

Нажалост, није забележен ниједан говор његовог непријатеља Публија Корнелија Сципиона Афричког, који је победио Ханибала у тој бици, али је сачувана беседа његовог млађег брата Луција Сципиона (190. пре н. е.).

\section{2. Беседа Луција Сципиона приликом примања заповедништва}

Дошао сам овамо не да робим и палим, већ да побеђујем; не да стичем благо, него славу. Свима онима који нису достојни да се боре под римским орлом заповедам да се удаље из моје војске. Само храбром и племенитом војнику пристоји да пркоси свим тегобама и опасностима и да страх, угодност и грабљивост одгони од себе.

Тако хоће Сципион војвода, тако хоће закони војнички!

Ова беседа не поштује правила композиције. Говорник, изоставивши титулацију и увод, почиње од основне идеје/мотива; цела беседа, од увода до закључка, прожета је том идејом.

\footnotetext{
${ }^{5}$ Ханибал је заиста друговао са војницима још од детињства, али и касније, када је постао врховни командант картагинске војске, борио се раме уз раме са својим војницима, тако да код њега тај поздрав није фарса већ искрено обраћање друговима, са којима је делио све недаће и невоље ратовања.
} 
За то постоји велики разлог - том беседом нови заповедник Сципион изграђује лични ауторитет код подређених. Својим говором он има за циљ да подигне морал у војсци, да изгради частан и поуздан колектив, у коме би владала ратничка врлина, тј. војничка част, а не животињски инстинкт грабљиваца који води једино у анархију. Њему је јасно да у анархији не могу владати ни најјачи умови, јер непредвидивост безумне масе без моралних окова немогуће је обуздати. Због тога, незадовољан стањем у војсци, мудри Сципион изнутра побуђује најузвишеније у сваком појединцу, изазива осећај кривице и жељу за славом. То постиже чврстином речи која је одраз његовог карактера. Сципион Млађи покушава да се уздигне изнад постојећег стања и да подстакне војнике на етичко поимање рата. Бескомпромисним ставом „Тако хоће Сципион војвода, тако хоће закони војнички!” говорник успева да задобије потпуно поверење код слушаоца и њихову беспоговорну убеђеност у исправност речи војсковође, а у исто време да им сугерише непогрешивост својих речи, као што је и сам закон непогрешив, другим речима да у свести војника изгради слику о истоветности себе и закона.

\section{3. Кнез Лазар Хребељановић (1329-1389)}

Ову беседу написао је Мавро Орбини. Она је плод легенди и предања, као и ауторове конструкције. Међутим, ипак ће бити анализирана јер се ни за друге беседе, иако се поуздано зна да су биле одржане, не може поуздано тврдити да су дословно изговорене тако како их данас читамо јер су ратничке беседе, као што је већ речено, најчешће импровизоване, па је писани траг о њима остављао неко други.

Срећа помаже смеле!

Куда, куда су ишчезли, храбри другови моји, оне ваше ретке врлине, чврстина и одважност с презиром саме смрти, врлине које су нас до данас, на огромну славу читаве Србије, уздигле изнад звезда? Шта можемо учинити? Можемо умрети, али као људи. Можемо учинити да нам пре дође онај коначни крај до којега сви рођени долазе, али на нашу корист, а на пропаст непријатеља. Зар није много боље славно умрети него срамотно живети? Зар се икад може боље умрети него пре но ито се жели смрт? Кажите ми, ако пристанете да будете њихови робови, зар нећете умрети као и други, кад сви морају умрети? Умрећете свакако, али уз бескрајно мучење, прекор, стид и срамоту не само вашу него читаве наше земље. Ох, зар није боље, кад се већ једном мора умрети, умрети наоружан и као частан човек него умрети и го, и у ланцима, и преклан као животиња? Ако сте уверени да свакако морате умрети, каква је то наивност ваша бојати се нечега што нико не може избећи. Смрт се не избегава одлагањем, али се зато много умањује слава кад се настоји да се избегне. Зар је смрт друго него свршетак и крај свих зала? Она, колико нам разум каже, не може бити тешка, јер бива у једном часу; ни горка, јер с њом престају све муке и патње; а зацело ни бедна ни досадна, јер бива само једном. Ако је, дакле, смрт таква, зашто се толико бојимо? Зашто да избегнемо једну смрт, мислимо ли умирати хиљаду пута на час? Нека бежи, нека бежи из ваше памети, из непобедиве словенске крви помисао на ропство. Ако се даље не може живети, умримо међу својим непријатељима, и то умримо наоружани против наоружаних. Други народи умиру у перју, обхрвани годинама, истрошени временом, мучени грозницом и хиљадама разних невоља: једино Словени умиру од мача, од мача умиру једино Словени! Али убија- 
јући део непријатеља и освећујући себе тако да и сами непријатељи, па макар били победници, увек оплакују њихову смрт. А ко зна, ако се одлучимо да будемо Словени, то значи славни и победници до сада у борби за сва места која газимо ми и која су газили наши преци, или да бар будемо људи који могу руковати мачем и знају храбро убијати и бити убијени, ко зна, рекох, да ми нећемо убијати њих исто тако добро као што и они нас? Срећа помаже смеле, а не доноси победу број, већ храброст војника и мудрост заповедника. На нашој страни је сва правда, јер је непријатељ ушао у нашу земљу и заузео многа места. У нужди смо која обично чини смелим и највеће кукавице; имамо толико оружја да ће нам, ако га будемо храбро употребили, или отворити пут свуда или створити тако велико друштво да ће сами непријатељи и остали оплакивати нашу смрт. Ако, дакле, ми ставимо све на коцку и, готово у очајању за свој спас, супротставимо се и храбро нападнемо непријатеља, уверићете се како очајање увек извлачи човека из невоља и доводи најчешће до највишег ступња задовољства о којем је једва и сањао!

Овде га сви у највећем заносу, распаљени словенским бесом, прекинуше узвиком: У бој! У бој!

Беседа почиње од реторског питања, на које сам говорник даје одговоре. Заправо је цела беседа проткана реторским питањима, питањима које себи нужно поставља сваки частан човек, сваки слободољубив грађанин и свако ко има национални идентитет. Ова беседа одликује се пре свега филозофским ставом. Шта је боље нечастан живот у ропству или смрт у борби за слободу?! Композицијски гледано, беседа има правилну структуру: аутор се прво обраћа народу, постављајући питање себи, као припаднику тог народа, затим прелази на основну идеју/мотив, износећи аргументе који бране његов став, а то су карактеристичне за војне беседе реминисценције славне ратничке историје (у овом случају прошлости Словена). Закључни део беседе садржи подстрек и храбрење војника, који се одражавају у чврстом убеђењу да није важан ни број ратника, нити ефикасност оружја, већ вера у победу и одлучност борбе, а све то овековечује изрека - Срећа прати смеле, која звучи као Божији благослов из уста његовог помазаника.

\section{4. Бајазит (1389)}

\section{Пред Косовску битку}

\section{Правоверни!}

Ми идемо на неверника. Алах који влада судбином нашом, предаће нам ђауре у руке ако смо верни Алаху и ако се држимо аманета које нам његов пророк Мухамед оставио. Зато, ако има кога међу вама који се не клања, који не држи рамазан, који не даје четрдесетину сиротињи, који је туђе узео, који зле мисли има на сриу - нека изађе из редова и иде својој кући; само праведни могу у ченет. Нека иде слободно, ја му нећу ништа учинити!

Увод се у овој беседи огледа у ословљавању и титулисању - Правоверни.

Та реч је пажљиво одабрана, Бајазит није ословио слушаоце са уобичајеним војним титулисањем: војници, јунаци, ратници, већ је од самог почетка беседе водио говор у одређеном правцу, у правцу буђења и подгрејавања религиозног осећања које је недвосмислено повезано код муслимана с ратним подвизима против хришћана. 
После кратког увода следи мотивација похода, која је аргументована Божјом, тј. Алаховом вољом. У циљу етичког прочишћења, што смо већ сретали у говору Сципиона, следи део о непожељности нечастивих, морално клонулих у редовима своје војске. На такав начин војсковођа жели себе да прикаже као узвишено биће, да створи јединствен дух чисте вере у божански циљ и значај предстојеће битке и уједно да има војнике са војном самосвешћу.

\section{5. Наполеон Бонапарта}

Сам Наполеон је за ову заповест рекао „Кратко и енергично” (Courte et energique!)

Уочи битке за Москву 1812. године код села Бородино

\section{Ратници!}

Ето битке коју сте толико желели! Победа је у вашим рукама. Она нам је нужна; њоме ћемо прибавити све што нам је потребно, удобне станове и повратак домовини. Борите се онако како сте се борили код Аустерлица, Витјебска и Смољенска. Нека се будућа покољења поносно сећају ваших јуначких дела данашњед дана! Нека кажу за сваког од вас: он је учествовао у великој бици код Москве.

Наполеон ову беседу почиње титулисањем - Ратници. Иако се Бонапарта борио заједно са својим војницима и доказао као вичан војник, он то није злоупотребљавао или, пак, није их сматрао себи равним. Ни у једној од познатих беседа он се војницима не обраћа са Другови, Браћо и сл. Вероватно је желео да војници стално имају у свести да им се обраћа император ${ }^{6}$ који их поштује.

Беседа је изречена једноставним језиком, онаквим за који је и сам Наполеон тврдио да га војници разумеју. Аргументи у овој беседи су очекивана животна блага, што је једино примамљиво измореним војницима у тешким условима непрекидних борби.

Аутор се користи реминисценцијом пређашњих славних битака, с циљем да се врати вера у сопствену моћ и снагу, а непосредно затим поткрепљује мотив визијом славе у историји. Битан чинилац у беседи је стварање слике која сваком војнику појединачно пружа осећај јунаштва. Наполеон је био свестан да је немогуће стварање колективне свести без увида у свест појединца.

\section{6. Михаил Кутузов}

Уочи Бородинске битке 7. септембра 1812.

Погледајте ову икону, светињу вашег смерног поштовања, молитва небесима да се људи сједине против тирана који је узнемирио цео свет. Незадовољан тиме што је до сада већ уништио милионе Божијих створења, улеће овај богомрски тиран, познати бунтовник и прекршитељ божијих и људских закона, насилно у светиње, прска их крвљу, обара олтаре, па и сам ковчег, освећен иконама наше иркве, излаже скрнављењу. Зато будите уверени да ће Бог, чији су олтари тако увређени, бити с вама; будите уверени да ће Он својим штитом заклонити ваше редове, а свог непријатеља, мачем Светог Арханђела Михаила, потрти. С таквом вером и уздањем у Бога пођите у бој ка победи! С таквом вером и ја ћу се борити, уверен да ће моје сузне очи видети победу на нашој страни!

\footnotetext{
${ }^{6}$ Извор: Бранислав Нушић, Реторика наука о беседништву, Београд, 1938, стр. 77.
} 
Војници! Вршите свак своју дужност. Помислите на наше градове које је пламен сажегао; помислите на своје жене и децу, која од вас помоћ ишту; помислите на нашег цара и ваше господаре, који у вама гледају потпору своје снаге и, пре но што сунце зађе, обојте ово тле наше отацбине врелом крвљу нападача и његових војника!

Кутузов уместо титулисања користи императив - погледајте, чиме добија и одмах скреће војничку пажњу на оно што је најсветије за руског војника - икону. Икона као симбол вере и заштите код њих буди религиозно осећање и спремност на самопожртвовање. Затим следи прегршт негативних епитета који се односе на противника, који је представљен као оличење зла у једном човеку. Кутузов код својих војника тенденциозно изазива гнев и отпор не према целој француској војсци, већ према појединцу који чини злодело. Појединачно набрајајући сва светогрђа која је тај ужасни тиранин чинио, искусни оратор наводи војнике да Наполеона поистовете са ђаволом. Самим тим њихова борба добија много већу димензију и метафизички значај борбе добра са злом. Руски војници у својој свести уз Архангела Михаила постају Божији ратници, иако посреди није верски сукоб. Међутим, Кутузов вешто користи религиозност руског војника, негује је и храни.

У закључном делу војсковођа им се директно обраћа - Војници, да би их натерао на размишљање три пута понавља императив „помислите”, подсећајући их на све што је непријатељ урадио њиховој земљи и најближима, подсећа их на оданост цару, а на крају следи императив, који овде представља наредбу „Обојте ово тле наше отацбине врелом крвљу нападача и његових војника!"

\section{7. Михаил Кутузов}

Говор руским војницима и француским заробљеницима

Хвала вам свима!

Хвала вам свима на тешкој и оданој служби. Победа је потпуна и Русија вас неће заборавити. Нека вам је слава довека!

Ево шта је, браћо! Знам тешко вам је, али шта ћемо! Стрпите се мало, неће ово још дуго трајати. Избацићемо госте, па ћемо одахнути. Цар неће заборавити како сте му служили. Вама је тешко, али сте ипак код куће; а ови, видите на какве су гране пали. Горе им је него најбеднијим просјацима. Док су били јаки нисмо их жалили, а сада их можемо и пожалити. И они су људи. Није ли тако, момци ?! Али треба рећи и то, ко их је звао код нас?! Право им буде. Пасја им мајка!

Ово је беседа - захвалница, у којој чувени војсковођа одаје признање својој војсци, хвали је и као официр и као припадник свог народа. Војницима се обраћа са „браћо”, чиме наглашава чињеницу да их разуме и да зна како се осећају и колико им је тешко. „Цар вас неће заборавити” није случајно изговорено, већ опомиње војнике да се и даље достојанствено понашају, јер и као победници представљају свог господара, а уједно им улива наду у бољи живот. Мотив жаљења слабијег, изражен у овој беседи, опет војнике подсећа на хришћанска начела, а непосредно после тога следи и чисто људска осуда у изјави „Али треба рећи и то, ко их је звао код нас?! Право им буде. Пасја им мајка!",, која почиње са реторским питањем „Није ли тако, момци?!", чиме говорник жели поново да истакне да потпуно разуме своје војнике. 


\section{8. Аугуст Макензен}

Дневна заповест пред напад на Србију 1915.

\section{Војници!}

Ви не идете ни на италијански, ни на руски или фрранцуски фрронт. Ви полазите у борбу против једног опасног, жилавог, храброг, енергичног непријатеља. Ви идете сад на српски фронт, против Србије, а Срби су народ који воли слободу и своју отаибину и који се за њу бори и жртвује до последњег. Пазите због тога да вам овај малобројни непријатељ не помрачи славу и не обезвреди досадашње успехе славне немачке армије.

Аугуст Макензен, чувени немачки војсковођа, своју беседу започиње кратким титулисањем - Војници, после чега одмах прелази на недвосмислено упозорење. У беседи не покушава да оцрни свог непријатеља, већ напротив, велича његову срчаност и спремност на борбу до последње капи крви. Епитети које упућује непријатељској војсци нису хиперболични, већ је представљају реално, онакву каква она заправо јесте - жилава, храбра и енергична. Беседа је кратка и без прекомерног патоса.

У закључном делу опет је поменута основна идеја беседе - упозорење да се малобројни непријатељ не потцени и тиме не угрози сопствена слава и војничка част, што је највећа лична светиња за сваког ратника.

\section{9. Драгутин Гавриловић}

У време одбране Београда 1915.

Јунаци!

Тачно у три часа непријатеља треба разбити вашим силним јуришем, разнети вашим бомбама и бајонетима. Образ Београда, наше престонице, мора да буdе светао.

\section{Војници! Јунаци!}

Врховна команда избрисала је наш пук из бројног стања, наш пук је жртвован за част Београда и отацбине. Ви немате, дакле, да се бринете за животе ваше, јер они више не постоје. Зато напред у славу! За краља и отацбину! Живео краљ!

\section{Живео Београд!}

Око 14.30 часова мајор Гавриловић је код кафане „Јасеница” прикупио три вода 2. и два вода 3. батаљона 10. пука, Сремски одред и остатке Жандармеријског одреда, одржао говор и у тачно 15.00 часова повео борце, окићене цвећем из једне дорћолске цвећаре, у јуриш.

Драгутин Гавриловић започиње ову беседу кратким титулисањем - Војници, којим подсећа слушаоце на њихову функцију, а то је да треба да ратују, то јест да бране своју земљу. У даљем тексту говорник даје недвосмислена упутства - шта треба слушаоци да чине. Конкретна акција и тачно време, које оратор наводи, чине психолошки фактор нужности и уобичајености, иако када би се реално размишљало о томе да војници наоружани бајонетима треба да се боре с непријатељем који их бомбардује из ваздуха, здрава логика спречила би их да крену напред. 
Међутим, Гавриловић издаје конкретну наредбу, с привидом да од њихове воље зависи успех операције - Непријатеља треба разбити!!! Разбити вашим силним јуришем!!! Људски фактор и патриотска одлучност - то је фактор који побеђује. Следећа реплика није мање експресивна - Образ Београда, наше престонице, мора да буде светао. Дакле, бели град не сме да буде окаљен и упрљан. Овде аутор користи метафорички обрт - светло/бело/чисто не сме да се оцрни и оскрнави, шамар не сме да падне на образ престонице, који овде представља српски народ у целини, а не само Београђане, дакле част народа не сме да буде укаљана.

У следећем пасусу следи директно обраћање уз употребу градације - Војници, Јунаци, којом говорник жели да укаже поштовање према храбрости војничкој која их чини јунацима.

Следи сурова истина - Врховна команда избрисала је наш пук из бројног стања, ваши животи више не постоје. Руководство не верује да ће иједна жива душа изаћи из те битке, што Гавриловић не крије од својих потчињених, указујући им тиме поштовање, Не лаже их, већ их на најсуровији начин суочава с истином. И једино што им преостаје је да славно погину за своју домовину и за оно што је сваком патриоти битно - краљ, отаџбина, престоница. Опозиција - ваши животи више не постоје - СМРТ / Живео краљ, живео Београд - ЖИВОТ, указује на војнички систем вредности, који се огледа у томе да се живот појединца жртвује зарад будућности нације.

\section{0. Мајор Милан Рафајловић}

У време одбране Београда 1915.

\section{Војници!}

Непријатељ је јак и бројно надмоћан. Ми смо за сада резерва одбране Београда, али ћете ускоро имати прилику да се као први покажете достојни оних који се већ јуначки боре. Нећу дуго говорити; ко хоће да мре тај ће вечно живети. Напред!

Беседа мајора Милана Рафрајловића одликује се концизношћу, одмереношћу, стиче се утисак да говорник не жели да губи време на дугачак говор када је сваки тренутак битан. У свакој реченици осећа се јак емотивни набој. Ова беседа састоји се од свега пет реченица, али садржи битну информацију с потконтекстом.

Беседа почиње титулисањем - Војници. Говорник не подилази слушаоцима звучним епитетима, назива их једноставно војницима, али треба имати у виду да се овде ради о резервистима и добровољцима, тако да за њих, који нису професионални војници, такво обраћање указује на поштовање. Говорник не улепшава стварност, напротив, упозорава слушаоце на бројну и оружану супериорност противника. У трећој реченици оратор исказом: „али ћете ускоро имати прилику да се као први покажете достојни оних који се већ јуначки боре" сугерише слушаоцима да нема свако ту част да ратује и да уђе у анале историје. У следећој реченици употпуњује мисао и алудира на то да се фризичка смрт награђује вечним животом у сећању захвалне нације. Ова беседа се одликује класичном композицијом војне беседе, фрункционално одговара прилици, свака реч је емоционално обојена, а уз то и одмерена, па самим тим има већу тежину. 


\section{Композицијска анализа}

Још од античких времена беседа је морала поштовати композицијску структуру, Платон је десинише као костур који чине:

$$
\begin{aligned}
& \text { ГЛАВА } \\
& \text { рука } \leftarrow \text { ТЕЛО } \rightarrow \text { рука } \\
& \text { НОГЕ }
\end{aligned}
$$

Глава (Exordium) - код војних беседа увод је јако кратак, углавном се своди на титулисање упућено слушаоцима, изражено срдачним вокативом говорника, чиме се одмах задобија пажња и расположење слушалаца. Најчешћа титулисања у војним беседама јесу: јунаци, витезови, војници, ратници, соколови, орлови, браћо, децо, синови моји.

Лева рука (Expositio) - у војној беседи подразумева осврт на прошлост (реминисценција), прави се паралела са ранијим нечасним понашањем непријатеља, наводе успеси своје војске, следе појединачна набрајања властитих победа током историје.

Тело (Fractatio) - у војној беседи представља главну мисао, која је у оваквим беседама више него у било којим другим једнозначна, јасна и бескомпромисна. Та мисао се намеће тако да се доживи као једина могућа опција.

Десна рука (Argumentatio) - то су аргументи, који у војним беседама нису научног карактера, а базирани су на народном убеђењу и веровањима.

Бог је са нама! Правда је на нашој страни! Срећа прати храбре! Боље смрт него ропство! Одбранићемо краља и отацбину!

Hore (Conclusio) - у војној беседи представљају закључак, који се најчешће своди само на команде као што су јуриш, напред, за мном.

Оно што Платон није узео у обзир говорећи о композицији јесте то да у сваком телу постоји душа, па тако уколико беседу разматрамо као тело са главом, телом и екстремитетима, онда она мора имати и душу.

Душа је заправо надахнуће говорника, који чак и ако није вешт беседник, својим искреним осећањима и заносом успева да поведе војску за собом. „За собом” је кључна синтагма у војним беседама, јер војсковођа, који након одржане беседе о томе како свако од нас треба да буде спреман да изгуби свој живот у борби, и како је дужан да брани отаџбину својом крвљу и животом, нареди војсци - Напред или Јуриш, чак и ако му је беседа била убедљива и надахнута, уколико не нареди - За мном, војско/браћо, доказавши тиме да је и сам спреман да учини оно што тражи од својих војника, неће оставити утисак племенитог и искреног човека, па самим тим ризикује да изгуби поверење подређених.

\section{Ауторитет говорника}

Ауторитет војсковође у војсци најлакше се гради захваљујући јунаштву. У војним беседама визуелни утисак, боја гласа, образовање, па чак ни реторичка вештина немају тако велику улогу као код беседа другог карактера. Овде је најважније да је говорник постигао ауторитет код слушаоца делима, а у самој беседи да је био искрен и уверљив. Многе војсковође током историје били су одабрани од народа/војника. Тако 
је било и у случају Ђорђа Петровића Карађорђа, који у чувеном говору у Орашцу 1804. одговара народ од тога да их он води, упозоравајући да ће бити строг и прек. На његов говор слушаоци одговарају - Хоћемо баш тебе - Онда хоћу и ја Вас!!! (то ће много касније вешто искористити и С. Милошевић - Волим и ја вас).

Фигура владара - цара/краља/кнеза и сл. на бојном пољу је највећа мотивација за војнике. Владар који се бори раме уз раме са својим војницима својим делима ће охрабрити војнике и подићи морал, чак и да никада не држи говор. Александар Македонски као и Јулије Цезар у одлучујућим беседама знали су да скину одећу и покажу војницима многобројне ране и ожиљке, као доказ да се са њима боре раме уз раме.

Као сликовит пример колико велики утицај има присуство владара на бојном пољу може послужити беседа Петра I Карађорђевића уочи битке на Колубари 1915, после које су изнемогли и израњавани војници смогли снаге да се боре даље, а када се прочуло да се краљ налази у рововима заједно с војницима редове војске муњевито су попунили дечаци и омладина из околних места.

Ја, пак Ваш стари пријатељ, остајем овде са својим синовима да умрем на овим положајима, јер ако непријатељ жели да заузме Србију мораће да пређе преко леша вашег краља и лешева његових синова!

\section{Општа места и стилске фигуре}

Иако су војне беседе увек надахнуте и набијене емоцијама, и у њима постоје општа места, која подстичу слушаоца на одлучнију борбу за најсветије што постоји у њиховој свести. Код словенских народа то су: Света земља (отаџбина); јунаштво и чојство; светли образ; срце јуначко; напаћена земља; мајка Србија/Русија; жене, сестре, кћерке и старци.

\section{Реторско/реторичко питање}

Навешћемо део говора командира прве чете Четрдесетог пешадијског пука капетана Луке Ђурашковића ${ }^{7}$ војницима 26. маја 1940. у Помореки, код Брезовица, који обилује реторичким питањима.

Слушај 'амо! Ми живимо у озбиљно доба и сваки од вас знаде зашто сте ту. Сви сте скоро већ старији и жењени људи, ви читате новине, је ли тако. Ако нам ко пружи pam, ... га отац, ми ћемо прихватити и ратовати. У том случају, ... му пас матер, морали би ми да примимо борбу, па макар сви изгинули. То би било од нас часно, је л' тако!

\section{Стилске фигуре у војним беседама}

Градација - најчешће се јавља при обраћању: ВОЈНИЦИ! ЈУНАЦИ! ВИТЕЗОВИ! ОРЛОВИ! БРАЋО! ДЕЦО! СИНОВИ МОЈИ! Говорник токОМ беседе обично ословљава слушаоце у градационом поретку, почевши при титулисању од војници, па у даљем тексту појачава експресивност при употреби маркиранијих речи.

\footnotetext{
${ }^{7}$ Говор командира прве чете, Четрдесетог пешадијског пука, капетана Луке Ђурашковића, сачуван у архиву САНУ (САНУ - А36-119-263).
} 
Систем одбране

Meтафора: Угасите непријатељском крвљу пожар московски; железне груди (Кутузов)

Синегдоха: Наш војник; наш брат; проклети Француз; проклети Турчин.

Алегорија: У царству ужаса (Суворов); 40 векова гледа на нас са врхова ових пирамида; немојте се осрамотити (Наполеон)

Хипербола: Бесмртност ваших имена (Петар I)

Метонимија: десно/лево крило

\section{Закључак}

Војне беседе су најкраћи жанр беседништва. За циљ имају побуђивање, развијање и подстицање патриотског духа код слушаоца. Такав говор мора да подигне морал војника и да подгрева војничку и националну свест. Војне беседе по функцији могу да се распореде у три категорије: пригодне, свечане и ратне. Све три врсте одликују се концизношћу, јасноћом говора и разумљивошћу изреченог, тако да основну идеју може схватити свако од слушалаца. Композиција војне беседе је сведена на: увод, тему и закључак. При чему је увод најчешће изражен једном речју - титулисањем, типа војници, јунаци, ратници. основна идеја је увек недвосмислено и концизно изречена, са што мањим бројем реченица, а закључак, као и увод, представљен је у једној речи или синтагми, типа: јуриш, напред, за мном и сл. Најзаступљеније стилске фигуре у војним беседама су: реторичко питање, метафора, синегдоха, хипербола, метонимија и алегорија. Неретко се срећу и устаљени идиоми, односно општа места.

За војну беседу најважнија је личност беседника. Као што је већ речено, ако је беседник уверљив, тј. ако верује у оно у шта жели да увери слушаоце, чему помажу његова искреност, чврст став и одлучност да прекине говор у сваком тренутку зарад окршаја с непријатељем, војници ће кренути за њим, поштоваће га и сматрати својим вођом. Важно је да беседник у закључку остане доследан и да позива војску за собом, „За мном, јуриш”, а не да их шаље испред себе. На тај начин ће заслужити још веће поштовање и поверење потчињених. Дакле, ауторитет беседника не гради се захваљујући образовању, реторском умећу, дикцији, изгледу и другим спољним факторима, већ захваљујући срчаности, личној и војничкој части, ${ }^{8}$ одлучности и претходним подвизима. Како рече Војвода Петар Бојовић: Старешине треба непрекидно да имају на уму крајњу сврху свог узвишеног позива и задатка - победу над непријатељем у рату и борбама по сваку цену за спас своје Отаџбине и народа, залажући за то нештедимице своју част и свој живот заједно са својим војницима.

\section{Лumepamypa}

1. Аврамовић C.: Rhetorike techne - вештина беседништва и јавни наступ, Београд, 2008.

2. Анушкин В.: Что есть риторика и возродится ли она в России?, Москва, 2001.

3. Апресян Г. 3.: Ораторское искусство, Москва, 1978.

\footnotetext{
${ }^{8}$ Раде Рајић, У име војничке части, Војноиздавачки завод, Београд, 2001., (135-155 стр.).
} 
4. Вајдић Ч.: Беседе, избор из војничког беседништва, Београд, 1996.

5. Веденская Л. А., Павлова Л. Г.: Культура и искусство речи.

6. Современная риторика, Ростов-на-Дону, 1998.

7. Зарецкая Е. Н.: Риторика: теория и практика речевой коммуникации, Москва, 2000.

8. Зверев С. Э.: Военная риторика в системе воспитания военнослужащих,

9. Современные исследования социальных проблем, Выпуск № 9 (17) / 2012, 10. www.sisp.nkras.ru

11. Љубибратић Р.: Војне беседе, Београд, 1987.

12. Миртов А.В.: Умение говорить публично, Тула, 2000.

13. Нушић Б.: Реторика - наука о беседништву, Београд, 1938.

14. Петровић С.: Реторика, Ниш, 1975 (Београд, 1995).

15. Рајић Р.: У име војничке части, Београд, 2001.

16. Станојевић О., Аврамовић С.: Ars rhetorica - вештина беседништва, Београд, 2002.

17. Тадић Љ., Реторика - увод у вештину беседништва, Београд, 1995.

18. Савкова 3. В.: Искусство оратора, Санкт-Петербург, 2003. 